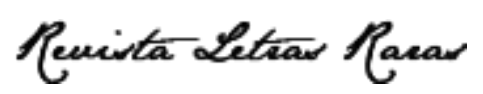

ISSN: 2317-2347 - v. 10, n. 3 (2021)

Todo o conteúdo da RLR está licenciado sob Creative Commons Atribuição 4.0 Internacional

\title{
Lembranças de uma vida sem COVID
}

\section{Cristóvão José dos Santos Júnior}

Doutor em Literatura e Cultura pela Universidade Federal da Bahia (UFBA).

(D) https://orcid.org/0000-0002-5797-7192

Recebido em: 17 ago. 2020. Aprovado em: 20 nov. 2020.

\section{Como citar este poema:}

SANTOS JÚNIOR, Cristóvão José. Lembranças de uma vida sem COVID. Revista Letras Raras.

Campina Grande, v. 10, n. 3, p. 379, set. 2021.

Eu tento me isolar com a memória do paladar sensível da euforia, tentando respirar na crematória atmosfera que a morte prenuncia...

E assim tento sentir a ambulatória recordação do olfato que luzia o contágio sonoro de uma história distante da febril claustrofobia...

Reminiscências de ecos de outra vida penetram meus pulmões e me atravessam na angústia traqueal adormecida...

Meus brônquios carcomidos nesta pena me impelem aos desejos que regressam do cárcere que achou sua quarentena...

\. cristovao_jsjb@hotmail.com 